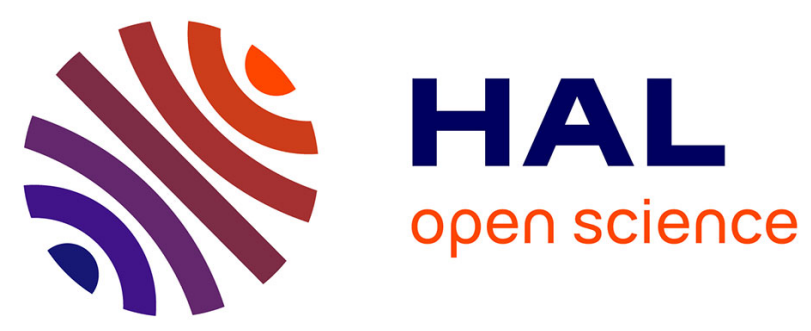

\title{
Use of reliable bioassays to detect potential hazard of food contact materials extracts to ensure quality, safety and innovation of paperboards
}

Emilie Souton, Isabelle Séverin, Marie-Christine Chagnon

\section{- To cite this version:}

Emilie Souton, Isabelle Séverin, Marie-Christine Chagnon. Use of reliable bioassays to detect potential hazard of food contact materials extracts to ensure quality, safety and innovation of paperboards. 51st Congress of the European Societies of Toxicology (EUROTOX), Sep 2015, Porto, Portugal. 51st Congress of the European Societies of Toxicology (EUROTOX), 238 (2, supplément), pp.S348, 2015, Toxicology Letters. hal-01985967

\section{HAL Id: hal-01985967 https://institut-agro-dijon.hal.science/hal-01985967}

Submitted on 18 Jan 2019

HAL is a multi-disciplinary open access archive for the deposit and dissemination of scientific research documents, whether they are published or not. The documents may come from teaching and research institutions in France or abroad, or from public or private research centers.
L'archive ouverte pluridisciplinaire HAL, est destinée au dépôt et à la diffusion de documents scientifiques de niveau recherche, publiés ou non, émanant des établissements d'enseignement et de recherche français ou étrangers, des laboratoires publics ou privés. 
